\title{
MINAT REMAJA MELANJUTKAN PENDIDIKAN KE PERGURUAN TINGGI DITINJAU DARI KONDISI EKONOMI KELUARGA DI DESA MANYABAR KECAMATAN PANYABUNGAN
}

\author{
Vitria Larseman Dela ${ }^{1}$ Kholilah $^{2}$ \\ Universitas Muhammadiyah Tapanuli Selatan ${ }^{1}$ \\ Email: vitria.larseman@gmail.com \\ Universitas Muhammadiyah Tapanuli Selatan² \\ Email: kholilah12@gmail.com
}

\begin{abstract}
ABSTRAK
Pendidikan memiliki peran penting dalam menunjukkan peradaban nasional. Pemerintah dituntut untuk berkonsentrasi pada peningkatan dan peningkatan kualitas dan kuantitas pendidikan secara berkelanjutan. Oleh karena itu penulis tertarik untuk meneliti minat remaja dalam melanjutkan pendidikannya ke pendidikan tinggi dalam hal kondisi ekonomi keluarga di desa Manyabar, Kecamatan Panyabungan. Tujuan dari penelitian ini adalah untuk menentukan tingkat ekonomi orang tua yang tertarik pada remaja melanjutkan pendidikan mereka ke perguruan tinggi. Pendekatan yang diambil dalam penelitian ini adalah tiga remaja yang tidak melanjutkan pendidikan ke perguruan tinggi. Pengumpulan data yang digunakan adalah observasi, wawancara, dan dokumentasi. Hasil penelitian ini menunjukkan bahwa kondisi ekonomi keluarga sangat mempengaruhi remaja di desa ini untuk melanjutkan pendidikan ke perguruan tinggi.
\end{abstract}

Kata Kunci: Remaja, Pendidikan, Perguruan Tinggi, Ekonomi

\section{ADOLESCENT INTERESTS CONTINUING EDUCATION TO HIGHER EDUCATION REVIEWED FROM FAMILY ECONOMIC CONDITIONS IN MANYABAR VILLAGE, PANYABUNGAN DISTRICT}

\begin{abstract}
Education has an important role in showing national civilization. The goverment is required to concentrate to improve and advance the quality and quantity of education continuously. Therefore the authort are interested in examining the interest of adolescents in continuing their education to higher education in terms of the family economic conditions in the manyabar village of panyabungan subdistrict. The aim to be achieved in this study is to determine the economic level of parents wits interest in adolescents continuing their education to college. The approach taken in this study are three teenagers who did not continue their education to college. Data collection used is observation, interviews, and documentation. The results of this study indicate that the economic cindition of the family strongly influenced adolescents in this village to continua their education to college.
\end{abstract}

Keywords: Teenage , Education, College, Economic 


\section{PENDAHULUAN}

Pendidikan nasional berfungsi mengembangkan kemampuan dan membentuk watak serta peradaban bangsa yang bermartabat dalam rangka mencerdaskan kehidupan bangsa, bertujuan untuk berkembangnya potensi peserta didik agar menjadi manusia yang beriman dan bertakwa kepada Tuhan Yang Maha Esa, berakhlak mulia, berilmu, kreatif, mandiri serta bertanggung jawab (Sudrajat, 2010). Pendidikan sering juga dipandang sebagai persiapan untuk kehidupan yang lebih baik di kemudian hari. Karena itu banyak orang tua yang tidak ragu-ragu memberikan pengorbanan yang besar untuk pendidikan anak-anaknya (Lisda Hayati, 2015).

Anak yang telah menamatkan sekolah diharapkan sanggup melakukan pekerjaan sebagai mata pencarian atau setidaknya mempunyai dasar yang cukup untuk mencari nafkah. Semakin tinggi pendidikan, semakin besar harapan untuk memperoleh pekerjaan yang baik (Rini, 2012). Minat remaja melanjutkan studi ke perguruan tinggi adalah kecenderungan yang mengandung unsur perasaan senang, keinginan, perhatian, ketertarikan, kebutuhan, harapan, dorongan, dan kemauan untuk melanjutkan pendidikan yang lebih tinggi serelah lulus sekolah menengah atas (Koban, 2007). Minat remaja kadang dipengaruhi oleh unsur-unsur keluarga dan lingkungan yang membuat remaja ragu untuk mwnentukan pilihan antara bekerja atau melanjutkan pendidikan.

Pada umumnya orang tua yang mampu atau berasal dari golongan yang lebih tinggi tingkat ekonominya akan lebih suka anaknya melanjutkan studinya ke perguruan tinggi dibandingkan dengan mereka yang berasal dari keluarga yang tingkat ekonomi rendah. Keluarga dengan tingkat ekonomi yang lebih rendah didesak untuk mencari pekerjaan guna mempertahankan nasibnya (Pratiwi, 2015). Banyaknya pilihan pendidikan manusia yang sesuai dengan kemampuan diri dan ekonomi orang tua. Namun dengan demikian untuk memperoleh pendidikan tersebut diperlukan biaya yang tidak sedikit jumlahnya. Biaya pendidikan yang tinggi kadang menjadi kendala bagi mereka yang berasal dari keluarga yang kurang mampu. Banyak dari mereka terpaksa putus sekolah atau tidak dapat melanjutkan studi kejenjang pendidikan yang lebih tinggi karena keterbatasan biaya (Sari, 2009). 


\section{LANDASAN TEORI}

Dari uraian tersebut di atas dapat diketahui bahwa untuk menempuh pendidikan yang lebih tinggi banyak faktor yang harus dipertimbangkan oleh remaja. Dari sekian banyak faktor tersebut dapat dipilih satu faktor yang diduga dominan berpengaruh terhadap pembentukan minat remaja untuk melanjutkan pendidikan keperguruan tinggi. Faktor tersebut adalah status sosial ekonomi orang tua. Pertimbangannya bahwa status sosial ekonomi orang tua merupakan faktor dominan yang mempengaruhi seorang anak dalam menentukan pilihan pendidikan ke jenjang yang lebih tinggi (Tari, 2015). Penelitian ini dimaksudkan untuk menyelidiki apakah faktor tersebut mempengaruhi minat remaja dalam melanjutkan pendidikan keperguruan tinggi. Banyak remaja di Desa Manyabar Kecamatan Panyabungan ini yang tidak melanjutkan pendidikan ke perguruan tinggi disamping ada permasalahan tentang perekonomian keluarga, juga kurangnya minat remaja untuk melanjutkan pendidikannya disamping dari faktor keluarga yang sangat dominan, ada juga pengaruh dari teman sebaya yang tidak melanjutkan pendidikannya. Ketertarikan remaja melanjutkan pendidikan ke perguruan tinggi sangat kurang dan pengetahuan remaja tentang perguruan tinggi serta universitas sangat minim. Berdasarkan hal itu peneliti tertarik untuk memperdalam permasalahan tersebut.

\section{METODE PENELITIAN}

Penelitian ini merupakan penelitian kualitatif dengan pendekatan deskriptif. Penelitian kualitatif adalah penelitian yang digunakan untuk meneliti pada kondisi objek alamiah dan peneliti merupakan instrumen kunci (Suryani, 2010). Subjek dalam penelitian ini adalah orangtua dan remaja yang tidak melanjutkan pendidikan perguruan tinggi. Penelitian ini difokuskan di Desa Manyabar Kecamatan Panyabungan. Alasan memilih Desa Manyabar Kecamatan Panyabungan sebagai lokasi penelitian, sebagai berikut:

1. Terdapat banyak remaja yang tidak melanjutkan pendidikan ke perguruan tinggi.

2. Lokasinya mudah dijangkau karena terletak di pinggir kota Panyabungan. 
Subjek dalam penelitian ini adalah remaja yang berusia 19 yang berjumlah 3 orang dan menghabiskan sebagian besar waktunya di Desa Manyabar Kecamatan Panyabungan untuk aktivitas-aktivitas. Adapun yang menjadi sumber data dalam penelitian ini adalah orangtua remaja, remaja dan kepala Desa. Teknik pengumpulan data yaitu dengan melakukan observasi, wawancara dan dokumentasi. Teknik analisis data yaitu dengan data reduction (reduksi data), data display(penyajian data), dan Conclusion Drawing(Verivication), (Mutiara, 2016).

Alat pengumpulan data dalam penelitian ini menggunakan observasi yaitu peneliti melakukan pengamatan secara langsung ke objek penelitian. Wawancara bertukar informasi dan ide melalui tanya jawab terhadap responden. Selanjutnya juga dokumentasi yang merupakan bentuk gambar, tulisan, vidio, foto dan lainlain sebagai pelengkap dalam penelitian kualitatif (Reyander, 2015).

\section{Responden Penelitian}

Responden pada penelitian ini adalah remaja lulusan SMA atau SMK yang tidak melanjutkan Pendidikannya ke Perguruan Tinggi Ditinjau dari Kondisi Ekonomi Keluarga di Manyabar Kecamatan Panyabungan. Karakteristik responden dalam penelitian ini dapat dilihat pada tabel di bawah ini.

Tabel 1. Karakteristik Responden Penelitian

\begin{tabular}{|l|l|l|l|}
\hline No. & \multicolumn{1}{|c|}{ Nama/inisial } & \multicolumn{1}{c|}{ Umur } & \multicolumn{1}{c|}{ Jenis kelamin } \\
\hline 1. & SP & 19 tahun & Perempuan \\
\hline 2. & HP & 19 tahun & Perempuan \\
\hline 3. & RM & 19 tahun & Perempuan \\
\hline
\end{tabular}

\section{Informan Penelitian}

Informan dalam penelitian ini merupakan subjek yang dapat memberikan informasi tambahan yang diperlukan selama proses penelitian. Adapun informannya penelitian ini adalah sebagai berikut:

Tabel 2. Karakteristik Informan Penelitian

\begin{tabular}{|l|l|l|l|l|}
\hline No. & Nama/inisial & \multicolumn{1}{|c|}{ Umur } & \multicolumn{1}{|c|}{$\begin{array}{c}\text { Jenis } \\
\text { kelamin }\end{array}$} & $\begin{array}{c}\text { Hubungan dengan } \\
\text { responden }\end{array}$ \\
\hline 1. & SH & 43 & Perempuan & Keluarga SP \\
\hline 2. & SN & 45 & Perempuan & Keluarga HP \\
\hline 3. & PY & 46 & Perempuan & Keluarga RM \\
\hline 4. & AM & 45 & Laki-laki & Kepala Desa \\
\hline 5. & MP & 44 & Laki-laki & Tokoh Masyarakat \\
\hline
\end{tabular}




\section{HASIL DAN PEMBAHASAN}

1. Minat Remaja Melanjutkan Pendidikan Ke Perguruan Tinggi Ditinjau Dari Kondisi Ekonomi Keluarga Di Desa Manyabar Kecamatan Panyabungan.

Temuan penelitian terkait dengan masalah minat remaja melanjutkan pendidikan ke perguruan tinggi dan hasil wawancara yang peneliti dapatkan dari informan AM bahwa AM Menyatakan "menurut saya penyebab banyaknya remaja tidak melanjutkan pendidikannya ke perguruan tinggi adalah karna kurangnya pengetahuan anak dan orang tua tersebut tentang perguruan tinggi dan bisa jadi dikarenakan karna pendidikan orang tua yang rendah disamping faktor ekonomi keluarga yang sangat rendah.Dari pernyataan AM ini dapat peneliti simpulkan bahwa pendidikan orang tua juga sangat mempengaruhi tingkat pendidikan anaknya kurangnya pengetahuan orang tua tentang pendidikan akan berdampak pada anaknya selain itu, faktor ekonomilah yang sangat berdampak setelahnya.

Kemudian dari informan MP, peneliti mendapatkan hasil wawancara tersebut, MP Menyatakan "bahwa kurangnya pengetahuan remaja tentang pendidikan tinggi atau universitas dikarenakan kebanyakan remaja di kampung ini bersekolah di pesantren termasuk remaja perempuan sebagaimana kita ketahui bersama bahwa di pesantren anak didiknya tidak diperbolehkan memakai HP dan seperti kita ketahui sekarang melalui HP kita bisa mengetahui segala keadaan termasuk pengetahuan tentang universitas dimanapun”.

Dari pernyataan MP, dapat peneliti simpulkan bahwa kebanyakan remaja dikampung ini bersekolah di pesantren yang minim akan pengetahuan tentang universitas selain tidak diperbolehkan memakai HP mereka juga kurang bersosialisasi dengan dunia diluar pesantren.

2. Kondisi ekonomi keluarga di Desa Manyabar Kecamatan Panyabungan.

Temuan penelitian terkait dengan masalah kondisi ekonomi keluarga di Desa Manyabar Kecamatan Panyabungan, dan hasil wawancara yang peneliti dapatkan dari informen SH bahwa SH menyatakan “ saya bukannya melarang atau memutuskan pendidikan anak saya hanya sampai tingkat pendidikan SMA saya hanya memberikan pertimbangan kepada anak saya untuk melanjutkan 
pendidikan ke perguruan tinggi karna dia anak kedua dari 6 bersaudara masih banyak adek-adeknya yang masih ingin sekolah dan sama sekali saya tidak melarangnya hanya saja mungkin dia merasa kasihan melihat saya dan memilih mengalah demi pendidikan aek-adeknya".

Dari pernyataan SH dapat peneliti simpulkan bahwa tidak ada larangan dari orang tua untuk anak mereka melanjutkan pendidikan ke perguruan tinggi hanya saja ada pertimbangan yang mereka berikan kepada anak mereka tersebut karna masih banyak adek-adeknya yang masih sekolah.

Kemudian dari informen SN, peneliti mendapatkan hasil wawancara tersebut SN menyatakan "dia tidak melarang anaknya untuk melanjutkan pendiidkannya ke perguruan tingi terlebih dia satu-satunya anak perempuan di keluarga tersebut dia ingin yang terbaik untuk pendidikan anaknya, tapi anaknya memutuskan tidak ingin melanjutkan pendidikannya lagi apalagi setelah ayahnya meninggal semangat dia untuk melanjutkan pendidikan ke perguruan tinggi sangat memudar dikarenakan katanya dia kasihan melihat saya bekerja sendirian apalagi untuk bayar uang kuliah yang mahal.

Dari pernyataan SN dapat peneliti simpulkan bahwa tidak ada larangan dari orang tua untuk anak melajutkan pendidikannya ke perguruan tinggi apalagi dia satu-satunya anak perempuan di keluarga kami orang tua sangat menginginkan anaknya untuk terus melanjutkan pendidikannya tapi anak tersebut tidak mau karna dia merasa kasihan melihat ibunya yang bekerja sendirian setelah ayahnya meninggal apalagi untuk bayar uang kuliah.

Kemudian dari informen PY, peneliti mendapatkan hasil wawancara tersebut, PY menyatakan “ kami sebagai orang tua tidak pernah melarang anak kami untuk melanjutkan sekolahnya ke perguruan tinggi malah kami sangat mendukungnya di perguruan tinggi manapun yang dia mau, dulu dia sangat ingin melanjutkan pendidikannya setelah tamat dari SMA, tapi tiba-tiba dia memutuskan untuk tidak melanjutkan pendidikannya lagi kami bertanya apa penyebabnya dia bilang dia hanya tidak bersemangat lagi untuk kuliah dan saya berpikir karna banyak temannya yang tidak melanjutkan pendidikannya makanya dia jadi ikut-ikutan. 
Dari pernyataan PY dapat peneliti simpulkan bahwa mereka tidak melarang anak mereka untuk melanjutkan pendidikannya ke perguruan tinggi malah mereka sangat mendukung tapi anak mereka tidak ingin melanjutkan pendidikannya karna ikut-ikutan temannya yang tidak melanjutkan pendidikannya lagi.

Dari semua pernyataan informan tersebut dapat peneliti simpulkan bahwa minat remaja melanjutkan pendidikan disini sangatlah minim apalagi dikaitkan dengan faktor ekonomi keluarga disamping minimnya pengetahuan mereka tentang universitas tersebut mereka juga dapat terpengaruh oleh teman sebaya ataupun lingkungan. Dan pendidikan orang tua mereka yang sangat rendah membuat mereka menjadi susah mendapatkan informasi tentang pendidikan diluar dari pendidikan setelah tamat SMA.

Melalui layanan informasi untuk meningkatkan pengetahuan orang tua tentang universitas, peneliti dapat memberikan langsung pengetahuan tentang pentingnya menuntut ilmu dan pengetahuan tentang perguruan tinggi bahwa ada bantuan bagi mahasiswa yang kurang mampu untuk terus bisa melanjutkan pendidikannya ke perguruan tinggi tanpa harus memikirkan biaya, dan untuk menambah wawasan orang tua tentang perguruan tinggi bahwa banyak program studi yang ada diperguruan tinggi manapun agar anak bisa memilih sesuai jurusan yang ia minati agar anak tidak memutuskan pendidikannya hanya sampai jenjang SMA saja, dan setelah mengetahui bahwa ada bantuan bagi mahasiswa yang kurang mampu di perguruan tinggi mereka jadi bisa dengan semangat untuk terus melanjutkan pendidikan mereka dan dapat menggapai cita-cita yang mereka impikan selama ini.

Temuan penelitian terkait dengan masalah minat remaja melanjutkan pendidikan ke perguruan tinggi di Desa Manyabar Kecamatan Panyabungan, dan hasil wawancara yang peneliti dapatkan dari Responden SP bahwa SP menyatakan "Iya kak, saya sangat ingin kuliah tidak ada paksaan dari orang tua ataupun keluarga semua muncul dalam diri saya sendiri, tapi kak saya sedikit kecewa karna banyak pertimbangan dari keluarga untuk saya bisa melanjutkan pendidikan saya karna mahalnya biaya pendidikan sekarang kak”. Kemudian dari Responden HP bahwa HP menyatakan "Saya sangat ingin melanjutkan 
pendidikan saya kak ke perkuliahan tapi saya kasian melihat ibu saya yang bekerja sendiri dan sudah semakin tua untuk membiayai hidup saya apalagi untuk bayar uang kuliah yang begitu mahal kak."

Kemudian dari Responden RM bahwa RM menyatakan "Sebenarnya tidak ada faktor dari teman ataupun dari lingkungan yang memaksa saya harus kuliah atau tidak harus kuliah kak itu semua keputusan saya yang saya ambil sendiri kak saya hanya kurang bersemangat saja mau melanjutkan pendidikan ke perguruan tinggi kak karna banyak teman saya yang tidak melanjutkan pendidikannya kak".

Dari semua pernyataan responden dapat peneliti simpulkan bahwa ada keinginan dari masing-masing responden untuk melanjutkan pendidikan ke perguruan tinggi, niat mereka untuk melanjutkan pendidikan ke perguruan tinggi ada tapi karena faktor ekonomi dan kurangnya pengetahuan tentang perguruan tinggi yang mengakibatkan mereka tidak melanjutkan pendidikannya.

Melalui observasi dan wawancara serta mengkaji dokumen yang telah peneliti lakukan maka peneliti mendapatkan hasil yang telah dikumpulkan dan direduksi setelah itu dapat disimpulkan bahwa minat remaja untuk melanjutkan pendidikan ke perguruan tinggi di Desa Manyabar Kecamatan Panyabungan ada tiga remaja yang telah diwawancara oleh peneliti dalam hal ini peneliti memberikan layanan informasi hal ini dilakukan sebagai tindak lanjut dan untuk meningkatkan minat remaja melanjutkan pendidikan ke perguruan tinggi.

Dalam proses peningkatan minat remaja melanjutkan pendidikan ke perguruan tinggi peneliti melakukan bidang bimbingan belajar dan layanan informasi tentang perguruan tinggi berbagai macam program studi dan adanya bantuan bagi mahasiswa yang kurang mampu untuk melajutkan pendidikannya ke perguruan tinggi, dan setelah peneliti memberikan bidang bimbingan dan layanan informasi responden tersebut sedikit banyaknya telah mengetahui tentang universitas dan peneliti melihat ada peningkatan semangat belajar dalam diri responden lagi untuk melanjutkan pendidikannya ke perguruan tinggi 
Diskusi penelitian yang dilakukan peneliti dengan melakukan diskusi bersama teman sejawat dimana mendapati hasil bahwa data yang diperoleh sudah akurat melalui proses observasi, wawancara dan kajian dokumen mengenai objek sumber data juga sudah dilakukan dan mendapati hasil bahwa kepala desa, dan tokoh masyarakat desa manyabar mendukung remajanya untuk melanjutkan pendidikan ke perguruan tinggi sesuai dengan kemampuannya.Serta dimana kelapa desa, melakukan atau melaksanakan tugasnya dalam memperhatikan anak remaja disekitarnya agar dapat melanjutkan pendidikannya ke perguruan tinggi dan orang tuapun sudah mulai memperhatikan pendidikan anaknya lagi untuk melanjutkan pendidikannya ke perguruan tinggi.

\section{KESIMPULAN}

Berdasarkan hasil penelitian yang penulis lakukan mengenai minat remaja melanjutkan pendidikan ke perguruan tinggi ditinjau dari kondisi ekonomi keluarga di Desa Manyabar Kecamatan Panyabungan, maka penulis akan mengemukakan kesimpulan sebagai berikut:

1. Minat remaja melanjutkan pendidikan ke perguruan tinggi di desa Manyabar Kecamatan Panyabungan memang saya lihat banyak yang berminat untuk melanjutkan pendidikannya setelah menamatkan SMA tapi faktor ekonomi orang tualah yang menjadi penghambatnya,

2. Disamping faktor ekonomi orang tua yang rendah, dimana saya melihat mayoritas mata pencarian orang tua di desa ini hanya bertani yang kita ketahui bersama bahwa bertani tidak begitu menjanjikan hasil, dan banyak juga remaja yang kurang mengetahui bahwa banyak bantuan di universitas manapun baik bagi mahasiswa yang berprestasi maupun bagi mahasiswa yang kurang mampu untuk terus melanjutkan pendidikannya ke jenjang yang lebih tinggi lagi.

3. Selain dari faktor ekonomi saya juga melihat bahwa pendidikan orang tua juga sangat mempengaruhi minat remaja di desa ini untuk melanjutkan pendidikannya, dimana saya lihat di desa ini banyak orang tua dari remaja yang hanya lulusan dari SLTA atau SMA sederajat selain sebagai sumber motivasi yang selalu memberikan semangat tingkat pendidikan orang tua 
pun mampu memancing minat para remaja untuk terus melanjutkan pendidikannya.

\section{SARAN}

1. Kepala Desa

Disarankan untuk memberikan pemahaman tentang universitas kepada semua remaja di desa agar bisa melanjutkan pendidikannya bukan hanya sampai pada jenjang SMA saja.

2. Kepada Remaja

Diharapkan kepada remaja di Desa Manyabar Kecamatan Panyabungan agar tidak berhenti sampai di jenjang SMA saja, diharapkan agar terus melanjutkan pendidikannya sampai ke jenjang universitas jangan karna faktor ekonomi harapan kalian untuk melanjutkan pendidikan terhenti, banyak bantuan di universitas yang bisa meringankan biaya perkuliahan sampai dengan selesai.

3. Bagi Orang Tua

Agar senantiasa memberikan perhatian terhadap anak termasuk pada pendidikannya agar tidak berhenti sampai jenjang SMA saja, jangan menjadikan faktor perekonomian menjadi alasan anak tidak melanjutkan pendidikannya karna banyak bantuan di universitas bagi mahasiswa yang berprestasi ataupun bagi mahasiswa yang kurang mampu untuk terus melanjutkan pendidikannya.

4. Bagi Pembaca

Semoga hasil penelitian ini dapat dijadikan sebagai sumber informasi dan materi yang dapat menambah wawasan atau ilmu pengetahuan dengan masalah yang akan diteliti dan bisa menjadi acuan bagi peneliti selanjutnya.

5. Bagi Penulis Selanjutnya

Disarankan bagi peneliti selanjutnya agar melaksanakan penelitian lebih mendalam, dalam arti bukan hanya melihat gambaran dari setiap responden tetapi juga menelusuri secara mendalam permasalahan yang di hadapi responden tersebut, dan juga sebagai acuan untuk penelitian di masa yang 
akan datang dengan melakukan kelemahan-kelemahan yang terdapat dalam metode penelitian.

\section{DAFTAR PUSTAKA}

Hayati Lisda. 2015, Pengaruh Pendidikan Orang Tua, Pekerjaan Orang Tua, Pendapatan Orang Tua, Kecerdasan Emosional Siawa Dan Kreativitas Siswa Terhadap Hasil Belajar Siswa Kelas VIII IPS Terpadu Di MTsN Model Padang, Skripsi,Sumatera Barat, FKIP STKIP PGRI Sumatera Barat.

Koban, F.T Ernestin. 2007.Hubungan Antara Status Sosial Ekonomi Orang Tua, Prestasi Belajar dan Motivasi Belajar Dengan Minat Siswa Melanjutkan Studi Keperguruan Tinggi.Skripsi, Yogyakarta. FKIP. Universitas Sanata Darma Yogyakarta.hal 14.

Pratiwi, Komari Noor. 2015 "Pengaruh Tingkat Pendidikan, Perhatian Orang Tua, dan Minat Belajar Siswa Terhadap Prestasi Belajar Bahasa Indonesia Siswa SMK Kesehatan di Kota Tangerang”.

Rini, Setya Esti, 2012, Hubungan Tingkat Pendidikan Orang Tua dan Prestasi Belajar Siswa dengan Minat Siswa Melanjutkan Studi ke Perguruan Tinggi Pada SisWA Kelas XI SMA Negeri 1 Kalasan Tahun Ajaran 2011/2012, Skripsi, Yogyakarta, FKIP Universiras Negeri Yogyakarta.

Sari, Puspa Lia. 2009, Pengaruh Status Sosial Ekonomi Orang Tua Terhadap Minat Siswa Sekolah Menengah Kejuruan Untuk Melanjutkan Studi Ke Perguruan Tinggi, Skripsi, Yogyakarta, FKIP Universitas Negeri Yogyakarta, hal 1-2.

Tari, Putry Indriyani. 2015, Pengaruh Motivasi Belajar Dan Status Ekonomi Keluarga Terhadap Minat Melanjutkan Pendidikan Ke Perguruan Tinggi Pada Siswa Kelas XII SMA NEGERI 1 Minggir Slamet Tahun Ajaran 2015/2016, Skripsi, Yogyakarta.FKIF Universitas Negeri Yogyakarta hal 1.

Sudrajat,Akhmad, 2010, Defenisi Pendidikan Menurut Undang-undang No. 20 Tahun 2003, (https://akhmadsudrajad.wordpress.com.diakses 4 Desember 2010).

Suryani. 2010.Metodologi Penelitian. Jakarta: Rineka Cipta.

Mutiara. 2016. Pengertian metode observasi. (www.sarjanaku.com)

Reyander. 2015. Metode penelitian. ( rayendar.blogspot.com/2015/06) 